\title{
LEGAL PROTECTION EFFORT TOWARDS MARK OWNER FROM THE SHARE-IN JAR COSMETIC TRADE
}

\author{
Sheril Firdausy ${ }^{1 *}$, Anajeng Esri Edhi Mahanani ${ }^{2}$ \\ ${ }^{1}$ Student of Law Faculty, Universitas Pembangunan Nasional Veteran Jawa Timur, Surabaya \\ ${ }^{2}$ Lecturer of Law Faculty, Universitas Pembangunan Nasional Veteran Jawa Timur, Surabaya
}

Correspondence Email: sherilfirdausy21@gmail.com

Submission: July 23, 2021

Publication: September 3, 2021

\begin{abstract}
Abstrak. This study aims to analyze and understand the legal protection towards the mark owner from the share-in jar cosmetic trade and the legal consequences for business actors who do sharein jar cosmetic trade. The type of legal research used in this study is a normative juridical legal research method. The data collection in this study was conducted through a literature study from the laws and regulations, journals, research results, and books. The data analysis used in this research is the descriptive analysis method. The results of the study show that the legal protection towards the mark owner from the share-in jar cosmetic trade can be carried out through preventive and repressive legal protection efforts. Legal protection efforts are preventively carried out by registering the mark to get legal protection as a legal mark owner. Repressive legal protection efforts for trademarks can be done by litigation dispute resolution and non-litigation dispute resolution. The legal consequences for business actors who do share-in jar cosmetic trade are compensate for damages and/or ceasing all acts related to mark use. Therefore, it is recommended to the mark owner to provide cosmetics with trial or sample sizes. In this case, so that consumers try first about their compatibility with these cosmetics. On the other hand, business actors doing share-in cosmetic jar trade must make a license agreement with the mark owner. Furthermore, the government needs to include criteria for violations of right on mark in laws and regulations. This is purpose to increase legal protection towards the mark owner from the share-in jar cosmetic trade in the future.
\end{abstract}

Keywords:

Business Actor;

Cosmetic Trade;

Mark Owner;

Share-in Jar;

Trademark.

This work is licensed under a CC BY-4.0 License

\section{INTRODUCTION}

The flow of the economy in the world today is so fast, as evidenced by the rapid development of technology in trade. These technological developments facilitate economic traffic between countries where there is no need for a meeting between the seller and the buyer when conducting trade transactions. Therefore, someone can quickly become a business actor, where the competitiveness in the trading industry is getting bigger so that the mark is needed. Apart from being a distinguishing feature, 
the mark also has a promotional function that creates a mark image that can be judged by the perceived quality by consumers.

Currently, conducting trade transactions via the internet is something that often happens. Many small and large business actors trade their wares through electronic media, social media, and e-commerce. Products traded on electronic media also various, one of which is cosmetic products that are very popular with the public.

From time to time the cosmetic needs is also increasing both domestic and foreign cosmetic products. Cosmetics sold by these cosmetic companies are generally sold in standard or large sizes. When they want to buy a cosmetic, consumers will think twice, even they hesitate to buy it. In this case, consumers have doubts about the incompatibility of the products they buy. Therefore, many business actors take the opportunity to sell cosmetic products by repackaging them into smaller containers, commonly known as share-in jar or share-in-bottle. This packaging is in great demand by the public because they can buy the product they want at a cheaper price due to the small size that suits these consumers' needs. In addition, the share-in jar cosmetic trade is also easy to find because many are traded through e-commerce. According to Laudon and Laudan, e-commerce is a method of buying and selling products by consumers electronically and from company to company with a computer as a liaison for business transactions. ${ }^{1}$

The practice of share-in jar and share-in bottle in cosmetics violates the applicable provisions, one of which is regarding the mark. In this case, the mark is used by repackaging a product without permitting the owner of the right on the mark. Therefore, the right on mark is used by other parties without entering into a license agreement with the mark owner or owner of the right on mark. Based on Article 1 number 1 of Law of the Republic of Indonesia Number 20 of 2016 on Marks and Geographical Indications (hereinafter referred to as Law No. 20 of 2016), explains that:

"Mark means any sign capable of being represented graphically in the form of drawings, logos, names, words, letters, numerals, colors arrangement, in 2 (two) and/or 3 (three) dimensional shape, sounds, holograms, or combination of 2 (two) or more of those elements to distinguish goods and/or services produced by a person or legal entity in trading goods and/or services."

In addition, in terms of the safety of these cosmetics, it is also doubtful because the quality of products that have been repackaged cannot be guaranteed. If the product is damaged and harms other people, the mark will also be affected. Therefore, business actors who carry out share-in-jar cosmetic trade have committed acts that violate the law because they have harmed the mark owner for their actions.

${ }^{1}$ Pradana, Mahir. (2015). Klasifikasi Bisnis E-commerce di Indonesia. Modus, Universitas Atma Jaya Yogyakarta, 27(2), p. 163 
Research discussing the concept of the share-in jar connected to the mark has been carried out previously by Theda, who discussed legal protection towards the owner of the right on mark Skin 1004 from the share-in jar skincare trade. ${ }^{2}$ In addition, research conducted by Safitri discusses the legal consequences of business actors who use well-known foreign trademarks by repacking and being linked with National Agency of Drug and Food Control (NADFC). ${ }^{3}$ While this research discusses the legal protection effort towards the mark owner from the share-in jar cosmetic trade. In this case, it is carried out in a preventive and repressive manner (online dispute resolution on the Shopee website) and is associated with unlawful acts. Based on the description, this research has differences from previous studies and is considered to have novelty. Therefore, this research is interesting to discuss with the formulation of how legal protection towards the mark owner from the share-in jar cosmetic trade is? Furthermore, what are the legal consequences for business actors who share-in jar cosmetic trade?

Based on the description of the introduction above, this study aims to analyze and understand the legal protection towards the mark owner from the share-in jar cosmetic trade and the legal consequences for business actors who do share-in jar cosmetic trade. The benefits of this research are expected to be material in the development of science in law, especially in terms of marks, cosmetics, and trade practices in civil law in Indonesia.

\section{METHOD}

The type of legal research used in this study is a normative juridical legal research method by explaining laws and regulations related to the research problem. ${ }^{4}$ Normative juridical law research is doctrinal legal research by researching documents or literature. ${ }^{5}$ The data collection in this study was conducted through a literature study from the laws and regulations, journals, research results, and books. Furthermore, the data is classified and selected based on the existing problems. The data analysis used in this research is the descriptive analysis method, which is carried out through qualitative analysis of secondary data, including the content and structure of positive law. ${ }^{6}$ The analysis is carried out by connecting the concept of the share-in jar, which violates the right on mark owned by the mark owner, with the legal protection that can be done for the cosmetic mark owner.

\footnotetext{
${ }^{2}$ Theda, Almira Mey. (2020). "Perlindungan Hukum terhadap Pemegang Hak Atas Merek Skin Care Skin1004 Atas Penjualan Produk Kemasan (Share In Jar)". Undergraduate Thesis. Universitas Islam Negeri Syarif Hidayatullah Jakarta, p. 6.

${ }^{3}$ Safitri, Ribath. (2020). "Akibat Hukum Penggunaan Merek Pribadi oleh Pelaku Usaha terhadap Produk Merek Dagang Terkenal Asing Melalui Repacking". Dissertation. Universitas Negeri Semarang, p. 11.

${ }^{4}$ Qamar, Nurul \& Rezah, Farah Syah. (2020). Metode Penelitian Hukum: Doktrinal dan Non-Doktrinal. Makassar: CV. Social Politic Genius (SIGn), p. 99.

${ }^{5}$ Waluyo, Bambang. (2008). Penelitian Hukum dalam Praktek. Jakarta: Sinar Grafika, p. 15.

${ }^{6}$ Qamar, Nurul \& Rezah, Farah Syah. (2020). Op. Cit., p. 49.
} 


\section{ANALYSIS AND DISCUSSION}

\section{A. Legal Protection towards Mark Owner from the Share-in Jar Cosmetic Trade}

Share-in jar cosmetic trade is generally done online in marketing it. Repackaging activities with the share-in jar concept are carried out by dividing the whole product contents into several smaller packages to consumers buy a product with a smaller size. It aims that consumers can get the product with a cheaper price because of its smaller size, which suits the consumer's needs. The smaller size of share-in jar cosmetics makes consumers interested in buying them because of trying first about their compatibility with these cosmetics. Suppose consumers buy cosmetics with intact packaging, but it turns out that they are not suitable for use. In that case, they will feel a loss because they cannot use them so that the share-in jar cosmetics can benefit consumers and business actors who do share-in jar cosmetic trade.

Business actors who do share-in jar cosmetic trade but do not ask permission from the cosmetic mark owner will cause the mark owner to be harmed. In this case, there is no license agreement between the mark owner and the business actor. $^{7}$ Based on Article 83 section (1) of Law No. 20 of 2016, regulates that the registered Mark owner and/or Mark Licensee may file the lawsuit against other parties who unlawfully use the Mark that is similar to or identical for similar kinds of goods and/or services in the form of:

a. claim for damages; and/or

b. ceasing all acts related to the use of Mark.

Based on the condition above. it can be broken down into several elements, including:

1. There is a registered mark owner or mark licensee;

2. Can sue a party who uses a mark without rights that have equality on goods and/or services;

3. By way of a claim for damages or ceasing all acts related to the use of mark.

In the first element, the registered mark owner is the person who has registered his trademark. In this case, be the first mark owner to have the exclusive right granted by the State for a definite period to use his/her mark or authorize others to do otherwise. A registered mark licensee is a person who has entered into a license agreement with the registered mark owner to use his mark legally and has been requested for its registration to the Ministry of Law and Human Rights of the Republic of Indonesia.

${ }^{7}$ Mafulah, Hanim. (2020). Pengecualian Perjanjian yang Berkaitan Paten dan Lisensinya dalam Pengawasan Persaingan Usaha. SIGn Jurnal Hukum, CV. Social Politic Genius (SIGn), 1(2), p. 100. 
In the second element, the share-in jar cosmetic trade event is carried out by a business actor who uses a mark without rights, carried out without permission in the form of a license agreement with the mark owner. Therefore, the business actor has violated the rights of the mark owner. Mark owner rights that are violated by business actors who trade repackaged cosmetic products are regarding the right of the mark owner to get results from the use of the mark by other parties and the right of the mark owner to regulate the extent to which the mark is used.

The mark used by other parties with the permission of the mark owner in the form of a license agreement has regulated the rights and obligations of each party. The rights obtained by the mark owner are economic in the form of royalties. However, no license agreement was made in the share-in jar cosmetic trade, which caused the mark owner to not get his economic rights. Because this incident, the mark owner cannot license the brand or aprprove it. In the absence of approval, the mark owner cannot regulate the extent to which other parties own the use of the mark.

In the third element, the events carried out by business actors who share-in jar cosmetic trade, the mark owner can claim damages or cease all acts related to the use of the mark. In this case, the mark owner has been harmed by a business actor who share-in jar cosmetic trade on using a mark without permission. In addition, the mark owner is also harmed by the possibility of a deteriorating mark image if there are consumers who are harmed by the use of the share-in jar cosmetic product. In this case, share-in jar cosmetic products are carried out without guaranteeing originality because product modification is possible.

For the damage received, the mark owner has the right to claim for damages, as based on Article 1365 of the Colonial Regulations, Staatsblad Number 23 of 1847 on the Burgerlijk Wetboek voor Indonesie/the Civil Code (hereinafter referred to as the Civil Code), regulates that "every unlawful act that causes damage onto another person obliges the wrongdoer to compensate such damage".

Events carried out by business actors are unlawful acts, as based on the elements in Article 1365 of the Civil Code, which include: ${ }^{8}$

1. There is an action;

2. Acts that violate the law;

3. A party commits an error;

4. There is the damage suffered by the victim, in which the cosmetic mark owner is harmed by the share-in jar cosmetic trade carried out on his brand; and

5. There is a causal relationship between the act and the damage.

${ }^{8}$ Winastri, Rivo Krisna \& Priyono, Ery Agus. (2017). Tinjauan Normatif terhadap Ganti Rugi dalam Perkara Perbuatan Melawan Hukum yang Menimbulkan Kerugian Immateriil (Studi Kasus Putusan Pengadilan Negeri Istimewa Jakarta No. 568/1968.G). Diponegoro Law Journal, Universitas Diponegoro, 6(2), p. 3. 
In the firstelement, there is an action, namely an action taken by the perpetrator. The business actor's activity of doing a share-in jar cosmetic trade can be said to be an act. In the second element, actions taken by business actors to trade share-in jar products can be seen as unlawful acts such as acts that violate laws and regulations, or these actions violate the rights of other people whose rights are guaranteed by law, or such actions not under the legal obligations of the perpetrator, actions that are not under decency, and also actions that are contrary to community behaviour (morality). ${ }^{9}$ In this case, the act of the share-in jar cosmetic trade business actor violates the right on mark owned by the mark owner, in which the act was carried out without the permission of the mark owner in the form of a license agreement.

The third element is an error made by a party. In this case, based on the elements of error described in Article 1365 of the Civil Code, there is an element of intent, negligence, and the absence of justifying or forgiving reasons. ${ }^{10}$ Business actors carry out Share-in jar cosmetic trade to earn profits. In this case, I agree with what is described by Safitri, that repacking activity carried out intentionally to obtain instant profits using well-known foreign marks have bad intentions. ${ }^{11}$ In the fourth element, there is a loss suffered by the victim, namely the mark owner. The mark owner is harmed by the share-in jar cosmetic trade carried out on his mark, where the mark owner does not get the rights that he should get if the business actor and mark owner make a license agreement for the mark.

In the fifth element, there is a causal relationship between action and loss. Some actions result in a loss to a person, both definite and probable, which is not only about the loss received in the future. ${ }^{12}$ The cause of business actors in the share-in jar cosmetic trade cannot be known with certainty, but the purpose of someone trading is to get profit. Share-in jar cosmetic trade will be more profitable than making your own cosmetic mark, which does not need to take care of mark registration, NADFC registration, and so on to make cosmetics. For this incident, it is necessary to know what the mark owner can do to get legal protection. According to Satjipto Raharjo, legal protection is an effort to regulate interests in society by regulating things that are limited and protected from these interests. ${ }^{13}$ Legal protection can be carried out preventively or repressively. In this case, so that the mark owner can defend his rights by taking legal protection efforts.

\footnotetext{
${ }^{9}$ Arief, Moh. Zainol \& Sutrisni, S. (2014). Perbuatan Melawan Hukum dalam Transaksi Jual-Beli Melalui Internet Ditinjau dari Buku III KUHPerdata. Jendela Hukum, Universitas Wiraraja, 1(2), p. 40.

${ }^{10}$ Yuniarlin, Prihati. (2012). Penerapan Unsur-Unsur Perbuatan Melawan Hukum terhadap Kreditur yang Tidak Mendaftarkan Jaminan Fiducia. Jurnal Media Hukum, Universitas Muhammadiyah Yogyakarta, 19(2), pp. 7-8.

${ }^{11}$ Safitri, Ribath. (2020). Op. Cit., p. 183.

${ }^{12}$ Hadi, I Gusti Ayu Apsari. (2018). Perbuatan Melawan Hukum dalam Pertanggungjawaban Dokter terhadap Tindakan Malpraktik Medis. Jurnal Yuridis, Universitas Pembangunan Nasional Veteran Jakarta, 5(1), p. 105.

${ }^{13}$ Nola, Luthvi Febryka. (2016). Upaya Perlindungan Hukum Secara Terpadu bagi Tenaga Kerja Indonesia (TKI). Negara Hukum: Membangun Hukum untuk Keadilan dan Kesejahteraan, Pusat Penelitian Badan Keahlian DPR RI, 7(1), p. 40.
} 
Preventive legal protection is done to prevent something that might happen. The legal protection that can be done is to register the mark to get legal protection as a legal mark owner. Furthermore, Indonesia adheres to a first to file system. In this case, someone who first registers a trademark will get legal certainty to prove the first protected mark owner and not register a trademark similar to the previous mark. Thus, other parties must respect the rights of the trademark registrar as an absolute right. ${ }^{14}$

Mark registration is carried out by applying for trademark registration either by the applicant himself or by the applicant's proxy in Indonesian online or offline to the Minister. A person who has registered immediately his mark will get the right on the mark, which person has the exclusive right to use his mark for a certain period as regulated in Law No. 20 of 2016. By having a right on mark in the form of a mark certificate, the mark owner has the right to prevent and prohibit others from using or imitating his mark without the mark owner's permission. ${ }^{15}$

Besides being used alone, the mark owner can also permit other parties to use the mark. The granting of permission to use the mark to other parties can be done through a license. The license is carried out with an agreement requested for its recording to the Ministry of Law and Human Rights. With a license agreement, the mark owner and the mark user have a valid agreement regarding what agreement was agreed. The contents of the agreement can be arranged between the parties regarding the rights and obligations of each party. So that, the recipient of the mark can use the mark legally. ${ }^{16}$ The mark user is called the licensee, while the mark owner is called the licensor. ${ }^{17}$

Repressive legal protection is carried out to resolve problems that have occurred due to an act in the form of a violation. Repressive legal protection for trademarks can be done by litigation dispute resolution and non-litigation dispute resolution. Settlement of trademark disputes can use non-litigation dispute resolution methods, as based on Article 93 section (1) of Law No. 20 of 2016, regulates that:

"In addition to the lawsuit settlement as referred to in Article 83 the parties may settle disputes through arbitration or alternative dispute resolution."

Non-litigation dispute resolution or alternative dispute resolution, as based on Article 1 number 10 of Law of the Republic of Indonesia Number 30 of 1999 on Arbitration and Alternative Dispute Resolution, explains that:

\footnotetext{
${ }^{14}$ Asmara, Andre, et al. (2019). Studi Kasus Penerapan Prinsip First to File pada Pembatalan Merek Cap Mawar. Syiah Kuala Law Journal, Universitas Syiah Kuala, 3(2), pp. 186-187.

${ }^{15}$ Dewi, Chandra Gita. (2019). Penyelesaian Sengketa Pelanggaan Merek. Yogyakarta: Deepublish, p. 5.

${ }^{16}$ Suhyana, Fina Agustina, et al. (2021). Transaksi Ilegal Menggunakan Kartu ATM Milik Orang Lain. SIGn Jurnal Hukum, CV. Social Politic Genius (SIGn), 2(2), p. 139.

${ }^{17}$ Syarifuddin, Muhammad Setya Ady. (2019). Penyelesaian Sengketa dalam Perjanjian Lisensi Merek. Simbur Cahaya, Universitas Sriwijaya, 26(1), p. 30.
} 
"Alternative dispute resolution means a mechanism for the resolution of disputes or differences of opinion through procedures agreed by the parties, i.e. resolutions outside the courts by consultation, negotiation, mediation, conciliation, or expert assessment."

In addition, alternative dispute resolution can also be done through arbitration and online dispute resolution. ${ }^{18}$ Settlement of disputes over the use of trademarks without rights can also be carried out with a lawsuit if non-litigation dispute resolution cannot be resolved.

The lawsuit was submitted to the Commercial Court. A registered licensee can also submit lawsuit against using a mark without rights, either individually or with the mark owner. ${ }^{19}$ Based on Article 84 section (1) of Law No. 20 of 2016, regulates that:

"In the process of examination and to prevent greater damages, the Mark owner and/or Licensee as the plaintiff may request to the judge to cease all acts of production, circulation, and/or trades of goods and/or services of that Mark unlawfully."

\section{B. Legal Consequences for Business Actors who do Share-in Jar Cosmetic Trade}

Share-in jar cosmetic trade harms the mark owner because the repackaging is done without the mark owner's permission. Business actors who commit such actions will get legal consequences. Legal consequences are the consequences of legal actions committed by a party and legal events that occur. Legal events are events in the form of legal actions related to legal consequences. ${ }^{20} \mathrm{An}$ act is an act of a legal subject that aims to cause legal consequences. Legal acts can be divided into three, namely: ${ }^{21}$

1. One-sided legal action, is the will and statement of the will of the legal subject;

2. Double legal actions, are the will and the statement of the will of two legal subjects; and

3. Other legal actions, are legal actions that are known and unknown to the person concerned.

Share-in jar cosmetic trades are generally done in online marketplaces such as Shopee. Thus, the mark owner can resolve this dispute online. An online dispute resolution is a form of alternative dispute resolution through electronic media with the internet network. The disputing parties do not need to meetings

\footnotetext{
${ }^{18}$ Hariyani, Iswi, et al. (2018). Penyelesaian Sengketa Bisnis. Jakarta: PT. Gramedia Pustaka Utama, p. 2.

${ }^{19}$ Hanim, Lathifah. (2011). Perlindungan Hukum HaKI dalam Perjanjian Waralaba di Indonesia. Jurnal Hukum, Universitas Islam Sultan Agung, 26(2), p. 582.

${ }^{20}$ Soerjowinoto, Petrus. (2018). Ilmu Hukum: Suatu Pengantar (Buku Panduan Mahasiswa). Semarang: UPT Perpustakaan Unika Soegijapranata, p. 39.

${ }^{21}$ Ibid., pp. 40-41.
} 
directly in the settlement process. ${ }^{22}$ Claims made by the mark owner can be made by contacting the business actor through the chat facility on the Shopee website to stop the business activities of the mark product. Thus, the actions taken by the mark owner include online dispute resolution.

The online settlement action taken by the mark owner can be categorized as an alternative dispute resolution with the negotiation method because the method is carried out by communicating only with the disputing parties without involving other parties. Taking this action will benefit the parties, where the mark owner will benefit by not requiring a lot of time and money to file a lawsuit to stop the perpetrator from using his mark. Meanwhile, business actors who share-in jar cosmetic trade benefit because they do not compensate the mark owner for their actions.

Suppose in the negotiation process no agreement is reached regarding the termination of the share-in jar cosmetic trade. In that case, the mark owner can submit a report to Shopee through the "report this product" facility to request the product be removed from the list of selling products. This is because share-in jar cosmetic products are one of the lists of prohibited items and restricted by Shopee because they are related to trademarks belonging to third parties. ${ }^{23}$ With the abolition of these products, business actors can no longer trade these products. It can be seen that Shopee, as a third party, can decide whether the report is acceptable or not. Shopee as a third party cannot be said to be a mediator because the mediator in dispute resolution using the mediation method is only limited to providing advice to the parties. ${ }^{24}$ In addition, settlement using this method cannot be categorized as dispute resolution using the arbitration method because Shopee is not an arbitration dispute resolution institution. Dispute resolution through arbitration also requires an agreement from the parties if you want to resolve the dispute in this way. ${ }^{25}$ This action is an online dispute resolution because it is resolved online, namely through the Shopee website.

In addition to demands to remove products traded in marketplaces such as Shopee, business actors can also be sued by the mark owner based on Article 83 section (1) of Law No. 20 of 2016. The lawsuit was submitted because of an unlawful act committed by a business actor and detrimental to the mark owner. In

\footnotetext{
${ }^{22}$ Kurniawan, Shelly. (2019). Perbandingan Penyelesaian Sengketa Merek Berdasarkan Undang-Undang Merek Nomor 20 Tahun 2016 tentang Merek dan Indikasi Geografis Jo. Undang-Undang Nomor 30 Tahun 1999 tentang Arbitrase dan Alternatif Penyelesaian Sengketa dengan World Intellectual Property Organization Arbitration and Mediation Centre. Dialogia Iuridica: Jurnal Hukum Bisnis dan Investasi, Universitas Kristen Maranatha, 11(1), p. 108.

${ }^{23}$ Administrator. (2021, 25 February). Kebijakan Barang yang Dilarang dan Dibatasi. Shopee Limited. Retrieved at the date of 28 April 2021.

${ }^{24}$ Kusen, Stevana Ameliana. (2016). Hakekat Keberadaan Mediasi sebagai Alternatif Penyelesaian Sengketa Perdata di Pengadilan Negeri. Lex Crimen: Jurnal Elektronik Bagian Hukum Pidana, Universitas Sam Ratulangi, 5(6), p. 17.

${ }^{25}$ Nugroho, Susanti Adi. (2015). Penyelesaian Sengketa Arbitrase dan Penerapan Hukumnya. Jakarta: Kencana Prenada Media Group, p. 81.
} 
a broad sense, the loss can be understood as the loss of profit that the mark owner should obtain. ${ }^{26}$ Thus, the business actor must compensate the loss suffered by the mark owner based on Article 1365 of the Civil Code.

Compensation for the actions of business actors aims to restore the original state of objects that have suffered losses, both loss of objects and loss of potential profits. ${ }^{27}$ Claims for compensation made by the mark owner can be in the form of material and immaterial compensation. Material compensation is compensation based on actual losses felt by the party whose rights have been violated, namely the mark owner. ${ }^{28}$ Material compensation can be in the form of economic rights that should be obtained by the mark owner in the form of royalties.

Based on Article 1366 of the Civil Code, regulates that:

"A person is responsible, not only for the damage which he has caused by his act, but also for that caused by his negligence or recklessness."

Negligence that causes harm is something that the perpetrators do not consider. In this case, the business actor does not consider the effect of his actions that can harm other things. Immaterial compensation is compensation based on the possible intangible loss suffered by the mark owner. In this case, moral losses, ideal losses, and losses that cannot be measured in money, such as the decline in the mark's image due to the actions of business actors. ${ }^{29}$ Therefore, the business actor must provide compensation for the incident.

A lawsuit that the mark owner can make to claim his rights is submitted to the chairman of the Commercial Court in accordance with the residence of the business actor conducting the share-in jar cosmetic trade. There are five locations for the Commercial Court in Indonesia to submit a lawsuit, including Jakarta, Surabaya, Semarang, Medan, and Makassar. ${ }^{30}$ Based on Article 85 section (2) of Law No. 20 of 2016, regulates that:

"In the event that one of the parties resides outside the territory of the Unitary State of the Republic of Indonesia, the lawsuit is addressed to the Chief Justice of the Commercial Court of Central Jakarta."

Based on Article 85 section (7) of Law No. 20 of 2016, regulates that:

"Proceedings to the decision on the lawsuit as referred to in section

(1) must be completed not later than 90 (ninety) days upon the panel

\footnotetext{
${ }^{26}$ Nashrullah, M. Faiz. (2019). Resiko dan Ganti Rugi dalam Perikatan Perspektif Konvensional dan Syariah. Journal of Islamic Business Law, Universitas Islam Negeri Maulana Malik Ibrahim Malang, 3(4), p. 19.

${ }^{27}$ Ardiansah, A., et al. (2019). Penyelesaian Polemik Ganti Rugi sebagai Objek Pajak Atas Putusan Arbitrase untuk Pembangunan Nasional. Al-Risalah: Forum Kajian Hukum dan Sosial Kemasyarakatan, Universitas Islam Negeri Sulthan Thaha Saifuddin Jambi, 19(1), p. 6.

${ }^{28}$ Dewi, Chandra Gita. (2019). Op. Cit. , p. 169.

${ }^{29}$ Ibid., p. 170.

${ }^{30}$ Sari, Novita Permata \& Astariyani, Ni Luh Gede. (2019). Pengajuan Gugatan Ganti Rugi Merek Terkenal Berdasarkan Undang-Undang No. 20 Tahun 2016. Kertha Wicara: Journal Ilmu Hukum, Universitas Udayana, $8(3)$, p. 8.
} 
handling the case has received the case and can be extended to not later than 30 (thirty) days upon approval from the Chief Justice of the Supreme Court."

Based on Article 85 section (8) of Law No. 20 of 2016, regulates that:

"The decision on the lawsuit as referred to in section (1) enclosing legal considerations completely as the grounds for the decision must be pronounced in the publicly open trial."

Based on Article 87 of Law No. 20 of 2016, regulates that "decision of the Commercial Court as referred to in Article 85 section (8) is only subject to appeal to the Supreme Court".

Based on Article 88 section (1) of Law No. 20 of 2016, regulates that:

"The appeal to the Supreme Court as referred to in Article 87 is filed not later than 14 (fourteen) days after the date of pronouncing the decision or notifying the decision to the parties by having it registered to the clerk of the Commercial Court that has ruled the decision."

Based on Article 88 section (8) of Law No. 20 of 2016, regulates that:

"The proceedings and decision on the appeal to the Supreme Court must be completed not later than 90 (ninety) days after date of which the appeal is received by the Panel."

Based on Article 88 section (9) of Law No. 20 of 2016, regulates that:

"The decision on the appeal to the Supreme Court as referred to in section (8), enclosing legal considerations completely as the grounds for the decision, must be pronounced in a publicly open court."

Based on Article 89 of Law No. 20 of 2016, regulates that "the decision on the Commercial Court which is final and binding is subject to the judicial review".

\section{CONCLUSIONS AND SUGGESTIONS}

Based on the description of the analysis and discussion above, it can be concluded that the legal protection towards the mark owner from the share-in jar cosmetic trade can be carried out through preventive and repressive legal protection efforts. Legal protection efforts are preventively carried out by registering the mark to get legal protection as a legal mark owner. Repressive legal protection efforts for trademarks can be done by litigation dispute resolution and non-litigation dispute resolution. Litigation dispute resolution is settled in the Commercial Court by claiming compensation and/or ceasing all acts related to mark use. Non-litigation dispute resolution is resolved by alternative dispute resolution, mediation, arbitration, and online dispute resolution. The legal consequences for business actors who do sharein jar cosmetic trade are compensate for damages and/or ceasing all acts related to mark use. Based on the description of the conclusion, it is recommended to the mark owner to provide cosmetics with trial or sample sizes. In this case, so that consumers try first about their compatibility with these cosmetics. On the other hand, business 
actors doing share-in cosmetic jar trade must make a license agreement with the mark owner. Furthermore, the government needs to include criteria for violations of right on mark in laws and regulations. In this case, to increase legal protection towards the mark owner from the share-in jar cosmetic trade in the future.

\section{REFERENCES}

Administrator. (2021, 25 February). Kebijakan Barang yang Dilarang dan Dibatasi. Shopee Limited. Retrieved from https://shopee.co.id/docs/3000, at the date of 28 April 2021.

Ardiansah, A., et al. (2019). Penyelesaian Polemik Ganti Rugi sebagai Objek Pajak Atas Putusan Arbitrase untuk Pembangunan Nasional. Al-Risalah: Forum Kajian Hukum dan Sosial Kemasyarakatan, Universitas Islam Negeri Sulthan Thaha Saifuddin Jambi, 19(1), 1-16. doi: https://doi.org/10.30631/al-risalah.v11i01.146

Arief, Moh. Zainol \& Sutrisni, S. (2014). Perbuatan Melawan Hukum dalam Transaksi Jual-Beli Melalui Internet Ditinjau dari Buku III KUHPerdata. Jendela Hukum, Universitas Wiraraja, 1(2), 32-42.

Asmara, Andre, et al. (2019). Studi Kasus Penerapan Prinsip First to File pada Pembatalan Merek Cap Mawar. Syiah Kuala Law Journal, Universitas Syiah Kuala, 3(2), 184-201. doi: https://doi.org/10.24815/sklj.v3i2.11899

Colonial Regulations, Staatsblad Number 23 of 1847 on the Burgerlijk Wetboek voor Indonesie/the Civil Code.

Dewi, Chandra Gita. (2019). Penyelesaian Sengketa Pelanggaan Merek. Yogyakarta: Deepublish.

Hadi, I Gusti Ayu Apsari. (2018). Perbuatan Melawan Hukum dalam Pertanggungjawaban Dokter terhadap Tindakan Malpraktik Medis. Jurnal Yuridis, Universitas Pembangunan Nasional Veteran Jakarta, 5(1), 98-113. doi: http://dx.doi.org/10.35586/.v5i1.318

Hanim, Lathifah. (2011). Perlindungan Hukum HaKI dalam Perjanjian Waralaba di Indonesia. Jurnal Hukum, Universitas Islam Sultan Agung, 26(2), 571-589. doi: http://dx.doi.org/10.26532/jh.v26i2.210

Hariyani, Iswi, et al. (2018). Penyelesaian Sengketa Bisnis. Jakarta: PT. Gramedia Pustaka Utama.

Kurniawan, Shelly. (2019). Perbandingan Penyelesaian Sengketa Merek Berdasarkan Undang-Undang Merek Nomor 20 Tahun 2016 tentang Merek dan Indikasi Geografis Jo. Undang-Undang Nomor 30 Tahun 1999 tentang Arbitrase dan Alternatif Penyelesaian Sengketa dengan World Intellectual Property Organization Arbitration and Mediation Centre. Dialogia Iuridica: Jurnal Hukum Bisnis dan Investasi, Universitas Kristen Maranatha, 11(1), 97-113. doi: https://doi.org/10.28932/di.v11i1.1972

Kusen, Stevana Ameliana. (2016). Hakekat Keberadaan Mediasi sebagai Alternatif Penyelesaian Sengketa Perdata di Pengadilan Negeri. Lex Crimen: Jurnal Elektronik Bagian Hukum Pidana, Universitas Sam Ratulangi, 5(6), 14-22. 
Law of the Republic of Indonesia Number 30 of 1999 on Arbitration and Alternative Dispute Resolution (State Gazette of the Republic of Indonesia of 1999 Number 138, Supplement to State Gazette of the Republic of Indonesia Number 3872).

Law of the Republic of Indonesia Number 20 of 2016 on Marks and Geographical Indications (State Gazette of the Republic of Indonesia of 2016 Number 252, Supplement to State Gazette of the Republic of Indonesia Number 5953).

Mafulah, Hanim. (2020). Pengecualian Perjanjian yang Berkaitan Paten dan Lisensinya dalam Pengawasan Persaingan Usaha. SIGn Jurnal Hukum, CV. Social Politic Genius (SIGn), 1(2), 87-103. doi: https://doi.org/10.37276/sjh.v1i2.55

Nashrullah, M. Faiz. (2019). Resiko dan Ganti Rugi dalam Perikatan Perspektif Konvensional dan Syariah. Journal of Islamic Business Law, Universitas Islam Negeri Maulana Malik Ibrahim Malang, 3(4), 13-20.

Nola, Luthvi Febryka. (2016). Upaya Perlindungan Hukum Secara Terpadu bagi Tenaga Kerja Indonesia (TKI). Negara Hukum: Membangun Hukum untuk Keadilan dan Kesejahteraan, Pusat Penelitian Badan Keahlian DPR RI, 7(1), 35-52.

Nugroho, Susanti Adi. (2015). Penyelesaian Sengketa Arbitrase dan Penerapan Hukumnya. Jakarta: Kencana Prenada Media Group.

Pradana, Mahir. (2015). Klasifikasi Bisnis E-commerce di Indonesia. Modus, Universitas Atma Jaya Yogyakarta, 27(2), 163-174. doi: https://doi.org/10.24002/modus.v27i2.554

Qamar, Nurul \& Rezah, Farah Syah. (2020). Metode Penelitian Hukum: Doktrinal dan Non-Doktrinal. Makassar: CV. Social Politic Genius (SIGn).

Safitri, Ribath. (2020). "Akibat Hukum Penggunaan Merek Pribadi oleh Pelaku Usaha terhadap Produk Merek Dagang Terkenal Asing Melalui Repacking”. Dissertation. Universitas Negeri Semarang.

Sari, Novita Permata \& Astariyani, Ni Luh Gede. (2019). Pengajuan Gugatan Ganti Rugi Merek Terkenal Berdasarkan Undang-Undang No. 20 Tahun 2016. Kertha Wicara: Journal Ilmu Hukum, Universitas Udayana, 8(3), 1-12.

Soerjowinoto, Petrus. (2018). Ilmu Hukum: Suatu Pengantar (Buku Panduan Mahasiswa). Semarang: UPT Perpustakaan Unika Soegijapranata.

Suhyana, Fina Agustina, et al. (2021). Transaksi Ilegal Menggunakan Kartu ATM Milik Orang Lain. SIGn Jurnal Hukum, CV. Social Politic Genius (SIGn), 2(2), 138-156. doi: https://doi.org/10.37276/sjh.v2i2.92

Syarifuddin, Muhammad Setya Ady. (2019). Penyelesaian Sengketa dalam Perjanjian Lisensi Merek. Simbur Cahaya, Universitas Sriwijaya, 26(1), 27-41.

Theda, Almira Mey. (2020). "Perlindungan Hukum terhadap Pemegang Hak Atas Merek Skin Care Skin1004 Atas Penjualan Produk Kemasan (Share In Jar)". Undergraduate Thesis. Universitas Islam Negeri Syarif Hidayatullah Jakarta.

Waluyo, Bambang. (2008). Penelitian Hukum dalam Praktek. Jakarta: Sinar Grafika. 
Winastri, Rivo Krisna \& Priyono, Ery Agus. (2017). Tinjauan Normatif terhadap Ganti Rugi dalam Perkara Perbuatan Melawan Hukum yang Menimbulkan Kerugian Immateriil (Studi Kasus Putusan Pengadilan Negeri Istimewa Jakarta No. 568/1968.G). Diponegoro Law Journal, Universitas Diponegoro, 6(2), 1-18.

Yuniarlin, Prihati. (2012). Penerapan Unsur-Unsur Perbuatan Melawan Hukum terhadap Kreditur yang Tidak Mendaftarkan Jaminan Fiducia. Jurnal Media Hukum, Universitas Muhammadiyah Yogyakarta, 19(2), 1-11.

I Firdausy \& Mahanani. (2021). Legal Protection Effort towards Mark Owner from the I Share-in Jar Cosmetic Trade. SIGn Jurnal Hukum, CV. Social Politic Genius (SIGn), 3(1), I I 26-39. doi: https://doi.org/10.37276/sjh.v3i1.113 